\title{
Automated stable isotope sampling of gaseous elemental mercury (ISO-GEM) - Insights into GEM emissions from building surfaces
}

Martin Jiskra, Nicolas Marusczak, Kin-Hung Leung, Lucas Hawkins, Eric M. Prestbo, and Jeroen E. Sonke Environ. Sci. Technol., Just Accepted Manuscript • DOI: 10.1021/acs.est.8b06381 • Publication Date (Web): 22 Mar 2019

Downloaded from http://pubs.acs.org on March 26, 2019

\section{Just Accepted}

"Just Accepted" manuscripts have been peer-reviewed and accepted for publication. They are posted online prior to technical editing, formatting for publication and author proofing. The American Chemical Society provides "Just Accepted" as a service to the research community to expedite the dissemination of scientific material as soon as possible after acceptance. "Just Accepted" manuscripts appear in full in PDF format accompanied by an HTML abstract. "Just Accepted" manuscripts have been fully peer reviewed, but should not be considered the official version of record. They are citable by the Digital Object Identifier (DOIß). "Just Accepted" is an optional service offered to authors. Therefore, the "Just Accepted" Web site may not include all articles that will be published in the journal. After a manuscript is technically edited and formatted, it will be removed from the "Just Accepted" Web site and published as an ASAP article. Note that technical editing may introduce minor changes to the manuscript text and/or graphics which could affect content, and all legal disclaimers and ethical guidelines that apply to the journal pertain. ACS cannot be held responsible for errors or consequences arising from the use of information contained in these "Just Accepted" manuscripts.

This document is the unedited Author's version of a Submitted Work that was subsequently accepted for publication in Environmental Science \& Technology, copyright @ American Chemical Society after peer review. To access the final edited and published work see: https://pubs.acs.org/doi/10.1021/acs.est.8b06381 
1 Automated stable isotope sampling of gaseous elemental mercury

2 (ISO-GEM) - Insights into GEM emissions from building surfaces.

3

4 Martin Jiskra ${ }^{1,2, *}$, Nicolas Marusczak ${ }^{1}$, Kin-Hung Leung ${ }^{3}$, Lucas Hawkins ${ }^{4}$, Eric Prestbo ${ }^{4}$, 5 Jeroen E. Sonke ${ }^{1, *}$

6

7 10bservatoire Midi-Pyrénées, Laboratoire Géosciences Environnement Toulouse,

8 CNRS/IRD/Université de Toulouse, 31400 Toulouse, France

9 2Environmental Geosciences, University of Basel, 4056 Basel, Switzerland

$10{ }^{3}$ Tekran Instruments Corp., M1P 2P4 Toronto, ON, Canada

$11{ }^{4}$ Tekran Instruments Corp., 98125 Seattle, WA, USA

12

13 *martin.jiskra@unibas.ch, jeroen.sonke@get.obs-mip.fr 


\section{Abstract}

Atmospheric monitoring networks quantify gaseous elemental mercury (GEM) concentrations, but not isotopic composition. Here, we present a new method for automated and quantitative stable isotope sampling of GEM (ISO-GEM) at the outlet of a commercial $\mathrm{Hg}$ analyzer. A programmable multi-valve manifold selects $\mathrm{Hg}$ at the analyzer inlet and outlet based on specific criteria (location, time, GEM concentration, auxiliary

21 threshold). Outlet $\mathrm{Hg}$ recovery was tested for gold traps, oxidizing acidic solution traps, and activated carbon traps. We illustrate the ISO-GEM method in an exploratory study on the effect of building walls on local GEM. We find that GEM concentrations directly at the building surface (wall inlet) are significantly enhanced (mean $3.8 \pm 1.8 \mathrm{ng} / \mathrm{m}^{3}$ ) compared to $3 \mathrm{~m}$ from the building wall (free inlet) (mean $\left.1.5 \pm 0.4 \mathrm{ng} / \mathrm{m}^{3}\right)$. GEM $\delta^{202} \mathrm{Hg}(-1.26 \pm 0.41$ $\% 0,1 \mathrm{sd}, \mathrm{n}=16)$ and $\Delta^{199} \mathrm{Hg}(-0.05 \pm 0.10 \%, 1 \mathrm{sd}, \mathrm{n}=16)$ at the wall inlet were different

27 from ambient GEM $\delta^{202} \mathrm{Hg}(0.76 \pm 0.09 \%, 1 \mathrm{sd}, \mathrm{n}=16)$ and $\Delta^{199} \mathrm{Hg}(-0.21 \pm 0.05 \%$, $1 \mathrm{sd}$, $\mathrm{n}=16$ ) at the free inlet. The isotopic fingerprint of GEM at the wall inlet suggests that GEM emission from the aluminum building surface affected local GEM concentration measurements. These results illustrate the versatility of the automated $\mathrm{Hg}$ isotope sampling. 


\section{$\underline{\text { Introduction }}$}

Mercury (Hg) is a global pollutant that is predominantly emitted to- and transported through the atmosphere as gaseous elemental mercury $\left(\mathrm{Hg}^{0}, \mathrm{GEM}\right){ }^{1}{ }^{1}{ }^{2}$ Atmospheric dry deposition by vegetation uptake of $\mathrm{GEM},{ }^{3}$ or wet deposition as $\mathrm{Hg}{ }^{\mathrm{II}}$ in rainfall and snowfall represent the dominant $\mathrm{Hg}$ source to aquatic and terrestrial ecosystems. ${ }^{2}$ Local GEM concentrations are controlled by primary emission, deposition, in situ production from $\mathrm{Hg}(\mathrm{II})$ and re-emission processes. ${ }^{3}$ Understanding the sources and processes that affect atmospheric GEM is essential to predict future ecosystem exposure to $\mathrm{Hg}$. Current understanding of GEM dynamics and ecosystem loading is mainly based on concentration data from global Hg monitoring networks, but does not include source/process specific molecular or isotopic tracers.

$\mathrm{Hg}$ stable isotope measurements of GEM (which we use here interchangeably with TGM, total gaseous $\mathrm{Hg}$ ) are a new tool to identify GEM emission sources and transformation processes and thus better understand atmospheric GEM dynamics. ${ }^{4-9} \mathrm{Hg}$ currently has 5 useful isotope signatures that represent mass dependent isotope fractionation (MDF: $\delta^{202} \mathrm{Hg}$ ) and odd and even mass independent isotope fractionation (MIF: $\Delta^{199} \mathrm{Hg}, \Delta^{200} \mathrm{Hg}, \Delta^{201} \mathrm{Hg}, \Delta^{204} \mathrm{Hg}$ ). GEM sampled at terrestrial background sites far from anthropogenic emission sources is characterized by positive $\delta^{202} \mathrm{Hg}$ values and slightly negative $\Delta^{199} \mathrm{Hg}$ values. ${ }^{5-7,}$ 10, 11 Air affected by recent anthropogenic emissions exhibits mostly negative $\delta^{202} \mathrm{Hg}$ values and $\Delta^{199} \mathrm{Hg}$ values around zero, ranging from 0.2 to $-0.2 \%{ }^{4,5,8,9,12}$ These values are similar to the $\mathrm{Hg}$ isotope composition of coal, ${ }^{13-15}$ the dominant source of anthropogenic Hg emissions, illustrating the potential of Hg stable isotopes to fingerprint $\mathrm{Hg}$ sources.

GEM isotope signatures are very different from $\mathrm{Hg}^{\text {II }}$ in wet deposition, which has strongly positive $\Delta^{199} \mathrm{Hg}$ and $\Delta^{200} \mathrm{Hg}^{7,}{ }^{11}$ Studies show that vegetation and soil $\mathrm{Hg}$ have 
$\Delta^{199} \mathrm{Hg}$ and $\Delta^{200} \mathrm{Hg}$ values that resemble more closely the isotope signatures of GEM than those of wet deposition. ${ }^{7,10,11,16,17 ~} \mathrm{Hg}$ isotope mass balance of global soils and vegetation data suggest GEM plant uptake to be $3-4 x$ larger than Hg wet deposition. ${ }^{7}$ This has led to a re-appraisal of the foliar GEM uptake mechanism and the idea that the 'vegetation $\mathrm{Hg}$ pump' controls diurnal and seasonal GEM dynamics over terrestrial surfaces. ${ }^{3}$

Precise GEM isotope analysis, with $2 \sigma$ uncertainty $<0.1 \%$, requires 1000 -fold more Hg (10 nanograms) than GEM concentration analysis (10 picograms). An additional challenge is that GEM isotope sampling recovery must be near-quantitative, to avoid isotope fractionation artifacts during sampling. Manual GEM isotope sampling methods thus far have used classical Hg sorbents, such as gold 4 , 5, 11,18 or various activated carbon powders, $^{6,7,10,19,20}$ and accumulated GEM over periods of 1 - 30 days. Such manual sampling complicates the study of short-lived (hours) pollution or chemical reactivity events, diurnal GEM dynamics, or spatial Hg isotope gradients. In addition, manual sampling only makes marginal use of atmospheric $\mathrm{Hg}$ monitoring network infrastructure. The broader goal of this study was to design an automated stable isotope sampling application for GEM (ISO-GEM) able to resolve pollution or transformation events. The application should direct GEM isotopes onto multiple traps, based on predefined criteria, such as time (diurnal, other), space (multiple inlets), meteorology (temperature, humidity, wind direction) or pollution events (Hg or $\mathrm{CO}$ concentration triggers). The device ideally had to be compatible with the most common $\mathrm{Hg}$ analyzer used in $\mathrm{Hg}$ monitoring networks. More specifically, we focused on recovering analyzed $\mathrm{Hg}$ at the instrument detection cell outlet which has the advantage that $\mathrm{Hg}$ isotope recovery efficiency can be assessed from the GEM monitoring data. We tested different $\mathrm{Hg}$ trapping materials for GEM isotope sampling, and illustrate re-emission of GEM from building surfaces using the novel ISO-GEM sampling device. 
Materials \& Methods

\section{Instrumentation}

The Tekran ${ }^{\circledR} 2537 \mathrm{X}$ was developed in 2012 and expanded electronic command and control capabilities compared to earlier 2537 Models. The enhanced communication capabilities and modular firmware design provides the ability to develop researchspecific tools such as the ISO-GEM application used in this research. The $2537 \mathrm{X}$ analyzer also provides remote controlled access to its operating software and firmware plug-in modules. The $2537 \mathrm{X}$ analyzer pumps ambient air at $1.5 \mathrm{~L} / \mathrm{min}$ over a gold cartridge where the GEM is amalgamated and quantitatively trapped. During each 5 min collection cycle approx. 11 pg GEM are trapped on a gold cartridge if ambient air contains $\sim 1.5 \mathrm{ng} / \mathrm{m}^{3}$ GEM. ${ }^{21}$ The trapped GEM is then thermo-desorbed and analyzed by atomic fluorescence spectroscopy (AFS) in high purity, dry argon $(80 \mathrm{~mL} / \mathrm{min})$. After analysis the GEM is exhausted by the cell vent at the back of the $2537 \mathrm{X}$, where it is re-captured for $\mathrm{Hg}$ stable isotope analysis. A dual pair of gold cartridges allows continuous measurement, one cartridge collects GEM while the second one is analyzed. With the added capabilities of the 2537X, Tekran designed and manufactured a programmable multi-port sampling system (Tekran ${ }^{\circledR} 1115 \mathrm{i}$ ) specifically adapted for automated GEM isotope sampling (ISOGEM). The firmware plug-in controls the function of the Tekran ${ }^{\circledR} 1115 \mathrm{i}$ multi-valve manifold, determining both how the 2537X analyzer collects sample and the post-analysis flow path of the mercury measured by the instrument. The 1115i plug-in controls all valve positions, which are synchronized with the $2537 \mathrm{X}$ 5-min analysis cycles. The $1115 \mathrm{i}$ multivalve manifold was outfitted with 3 large 3-way valves (NResearch 648T032 with PFA 1/4" connectors), and 5 small 3-way valves (NResearch $225 \mathrm{~T} 032$ with PFA 1/8" connectors). The 3 large valves permit regular flow rate (1.5 $\left.\mathrm{L} \mathrm{min}^{-1}\right)$ sampling of GEM at 
up to 4 different physical locations (e.g. gradient, inside vs. outside a building, etc.). The 5 smaller valves are used to direct exhausted $\mathrm{Hg}$ at the 2537X cell vent, in a high-purity, dry argon flow rate of $80 \mathrm{~mL} \mathrm{~min}^{-1}$, to the dedicated $\mathrm{Hg}$ isotope traps. Inlet lines to the $2532 \mathrm{X}$ Tekran consisted of $1 / 4$ " PFA tube and exhaust lines consisted of $1 / 8$ " PFA tube. The original brass cell vent of the Tekran ${ }^{\circledR} 2537 \mathrm{X}$ was replaced by a PTFE cell vent to prevent potential sorption of GEM.

Atmospheric Temperatures were obtained for Toulouse-Blagnac $\left(43.62^{\circ} \mathrm{N}, 1.39^{\circ} \mathrm{E}\right)$ close to the GET Laboratory building through the French Meteo services (www.infoclimat.fr).

\section{Hg trapping methods}

Two trapping methods have been previously used to collect nanogram quantities of GEM for isotopic analysis: (i) amalgamation of GEM on gold coated quartz beads, ${ }^{4,5}, 11,18$ and (ii) activated carbon traps impregnated with halogens $(\mathrm{Cl}, \mathrm{I})^{6,7,10,19,20}$ or sulfur. ${ }^{22,23} \mathrm{~A}$ third method that is commonly used to trap GEM, not during ambient GEM sampling, but as part of laboratory pre-concentration methods, consists of purging GEM through a strongly oxidizing, acidic aqueous solution. ${ }^{13,24}$ There are important differences between direct manual sampling of GEM onto gold or activated carbon, and the ISO-GEM application: 1. Direct sampling is done in air at 1-2 $\mathrm{L} \mathrm{min}^{-1}$ flow rates, while 2537X cell vent trapping is done in low flow ( $80 \mathrm{~mL} / \mathrm{min})$ high purity, dry argon. 2. Direct sampling onto multiple, parallel gold traps is done for at most 1-3 days, while 2537X cell vent trapping in ISO-GEM applications will typically last 1-6 weeks in line with routine instrument maintenance schedules. The ISO-GEM trapping method therefore has to be robust and free of $\mathrm{Hg}$ breakthrough over prolonged sampling times. We tested several GEM trapping methods, namely gold-quartz traps, acid-traps and activated carbon traps impregnated with iodine (I-AC) and sulfur (HGR-AC). As the goal of this project was to 
132 develop an optimal ISO-GEM system, we chose an iterative development scheme, which 133 may result in the fact that not all conditions have been tested for all trapping materials. (Ref. \# 35-25500-00) were obtained from Tekran ${ }^{\circledR}$ Instruments. Iodated activated carbon powder (I-AC) was obtained from Brooks Rand. Sulfur impregnated activated carbon (Calgon HGR-AC, product no 2300, Calgon Carbon Corp.) was provided by F. Wania at the University of Toronto at Scarborough. I-AC (125mg) and HGR-AC (400 mg) powder was weighed and traps were prepared manually in $12 \mathrm{~cm}$ long Pyrex tubes ( 7 mm OD, $4 \mathrm{~mm}$ ID); the powder was held in place by a diameter constriction of the tube and two quartz wool plugs. Halogen sorbent traps, used to eliminate volatile iodine, were obtained in the form of LECO AMA-254 catalyst tubes (part No. 614-822-105) from

143 Symalab (France) and manually prolonged by $20 \mathrm{~cm}$. Bi-distilled $\mathrm{HNO}_{3}$ and $\mathrm{HCl}$ was 144 produced in-house, and high purity oxygen and ultra high purity dry (UHP) argon gas 145 was obtained from Air Products, France.

\section{Hg concentration analysis}

147 All analyses were performed at the temperature controlled $\left(21 \pm 1^{\circ} \mathrm{C}\right)$ Geoscience 148 Environnement Toulouse laboratory. Both gold bead and gold matrix traps were 149 desorbed and analyzed by dual amalgamation atomic fluorescence spectrometry (AFS, 150 Brooks Rand Model III, USA). The AFS was calibrated using manual GEM vapor injections 151 from an in-house thermostatted liquid/vapor Hg source. I-AC and HGR-AC traps were processed using protocols adapted from Fu et al.

$1532014 .{ }^{19}$ The method is based on dual-tube furnace combustion in an AMA-254 halogen 154 trap. I-AC and HGR-AC was combusted in a first oven under a continuous flow of Hg-free $155 \mathrm{O}_{2}\left(75 \mathrm{~mL} / \mathrm{min}\right.$ ) over $6 \mathrm{~h}$ by ramping temperature to $680^{\circ} \mathrm{C}$ (ramp $1: 5^{\circ} \mathrm{C} / \mathrm{min}$ to $120^{\circ} \mathrm{C}$, 
156

157

158

159

160

161

162

163

164

165

166

167

168

169

170

171

(Milestone) mercury analyzer. over the 2 years of research.

ramp 2: $1^{\circ} \mathrm{C} / \mathrm{min}$ to $250^{\circ} \mathrm{C}$, ramp 3: $2^{\circ} \mathrm{C}$ to $680^{\circ} \mathrm{C}$ ). The I-AC and $\mathrm{HGR}$-AC powders were placed in $10 \mathrm{~cm}$ quartz tubes closed with quartz wool. To increase the life-time of the catalyst tube and to reduce wall sorption of GEM the activated carbon traps were embedded with $1 \mathrm{~g}$ of additional trapping material on each side (Figure S1). For I-AC a halogen scrubber (mixture of $\mathrm{MnO}_{2}(70 \% \mathrm{w} / \mathrm{w}), \mathrm{CoO}(20 \% \mathrm{w} / \mathrm{w})$ and $\mathrm{CaO}(10 \% \mathrm{w} / \mathrm{w}$, pre-baked at $680^{\circ} \mathrm{C}$ for $2 \mathrm{~h}$ ) was used following the SDS 06112 of the AMA-245 (Leco) and for HGR-AC sodium bicarbonate $\left(\mathrm{Na}_{2} \mathrm{CO}_{3}\right.$, pre-baked at $500^{\circ} \mathrm{C}$ for $\left.2 \mathrm{~h}\right)$ was used following McLagan et at. $2017 .^{25}$ The second oven housed the halogen scrubber section, which was constantly kept at $680^{\circ} \mathrm{C}$. After the combustion oven GEM was introduced into a $8 \mathrm{~mL}$ oxidizing solution trap consisting of 40 volume\% inverse aqua regia (iAR, $4.2 \mathrm{~N} \mathrm{HNO}_{3}, 1.2$ $\mathrm{N} \mathrm{HCl})$ in a $15 \mathrm{~mL}$ Falcon tube. A custom-made type\#3 $(16-40 \mu \mathrm{m})$ porosity glass bubbler tube was used to generate small diameter bubbles.

Total Hg concentrations in 40vol\%iAR solutions were measured after dilution following the USEPA 1631 method. ${ }^{26}$ Aliquots of 0.2 - 2 mL were analyzed in duplicate on a semi-automatic cold vapor atomic fluorescence spectrometry (CV-AFS, Brooks Rand Model III, USA) using a single gold trap.

Hg levels recovered from different traps and measured by AFS were compared to GEM measurements of a Tekran ${ }^{\circledR} 2537 \mathrm{X}$ analyzer to determine sampling yields. The analyzer was regularly (23h) calibrated using its internal GEM permeation source, and was monthly calibrated by manual GEM vapor injections from the external GEM vapor source. All manual calibrations agreed within $5 \%$ of the permeation source calibration

Blank levels of the I-AC and HGR-AC powders were measured using a DMA-80 
181 Table 1: Summary of the performance of different tested trapping materials for Hg stable

182 isotope sampling. ${ }^{*}$ Samples collected at the exit of the Tekran 2537X cell vent in an ultra

183 high purity, dry (UHP) argon matrix. This does not represent trapping efficiency in

184 ambient air. BDL stands for below detection limit, numbers in brackets represent range.

$185{ }^{* *}$ including data reported in Ref. ${ }^{10}$

\begin{tabular}{|c|c|c|c|c|}
\hline $\begin{array}{l}\text { Trap } \\
\text { material }\end{array}$ & gold-trap* & acid-trap* & I-AC & HGR-AC \\
\hline description & $\begin{array}{l}\text { gold surface or } \\
\text { sand beads coated } \\
\text { with gold }\end{array}$ & $\begin{array}{l}40 \% \text { inverse Aqua } \\
\text { regia }\end{array}$ & $\begin{array}{l}\text { Iodine impregnated } \\
(10 \% \mathrm{w} / \mathrm{w}) \text { activated } \\
\text { carbon }\end{array}$ & $\begin{array}{l}\text { Sulfur impregnated } \\
\text { activated carbon }\end{array}$ \\
\hline Matrix & UHP Argon & UHP Argon & ambient air & ambient air \\
\hline $\begin{array}{l}\text { trap flow } \\
\text { (mL/min) }\end{array}$ & 80 & 80 & $\sim 300$ & $\sim 300$ \\
\hline $\begin{array}{l}\text { Time } \\
\text { sampled }\end{array}$ & $1-70 \mathrm{~h}$ & $24-210 \mathrm{~h}$ & $48-62 d$ & $48-62 d$ \\
\hline $\begin{array}{l}\text { Hg amount } \\
\text { (ng) }\end{array}$ & $0.2-12$ & $6-13$ & $11-32$ & $21-39$ \\
\hline Recovery (\%) & $66 \% \pm 27 \%(n=15)$ & $94 \% \pm 9 \%(n=13)$ & $97 \pm 39 \%(n=10)^{* *}$ & $95 \% \pm 4 \%(n=4)$ \\
\hline Breakthrough & $11 \%(2-19, n=12)$ & $<2 \%(\mathrm{n}=1)$ & BDL & BDL \\
\hline $\begin{array}{l}\text { Blank } \\
\text { (ng/trap) }\end{array}$ & BDL & $0.1 \pm 0.04$ & $0.32 \pm 0.1$ & $0.06 \pm 0.03$ \\
\hline advantage & $\begin{array}{l}\text { Simple handling } \\
\text { and good recovery } \\
\text { for short sampling } \\
\text { periods }(<16 \mathrm{~h})\end{array}$ & $\begin{array}{l}\text { Direct analysis of the } \\
\text { trap by MC-ICPMS }\end{array}$ & Good performance & Very good performance \\
\hline disadvantage & $\begin{array}{l}\text { Passivation of gold } \\
\text { traps at sampling } \\
\text { times exceeding }\end{array}$ & $\begin{array}{l}\text { i) Handling } \quad \text { acids } \\
\text { requires } \quad \text { training }\end{array}$ & $\begin{array}{l}\text { Additional } \\
\text { oven }\end{array}$ & $\begin{array}{l}\text { Additional } \\
\text { oven }\end{array}$ \\
\hline
\end{tabular}




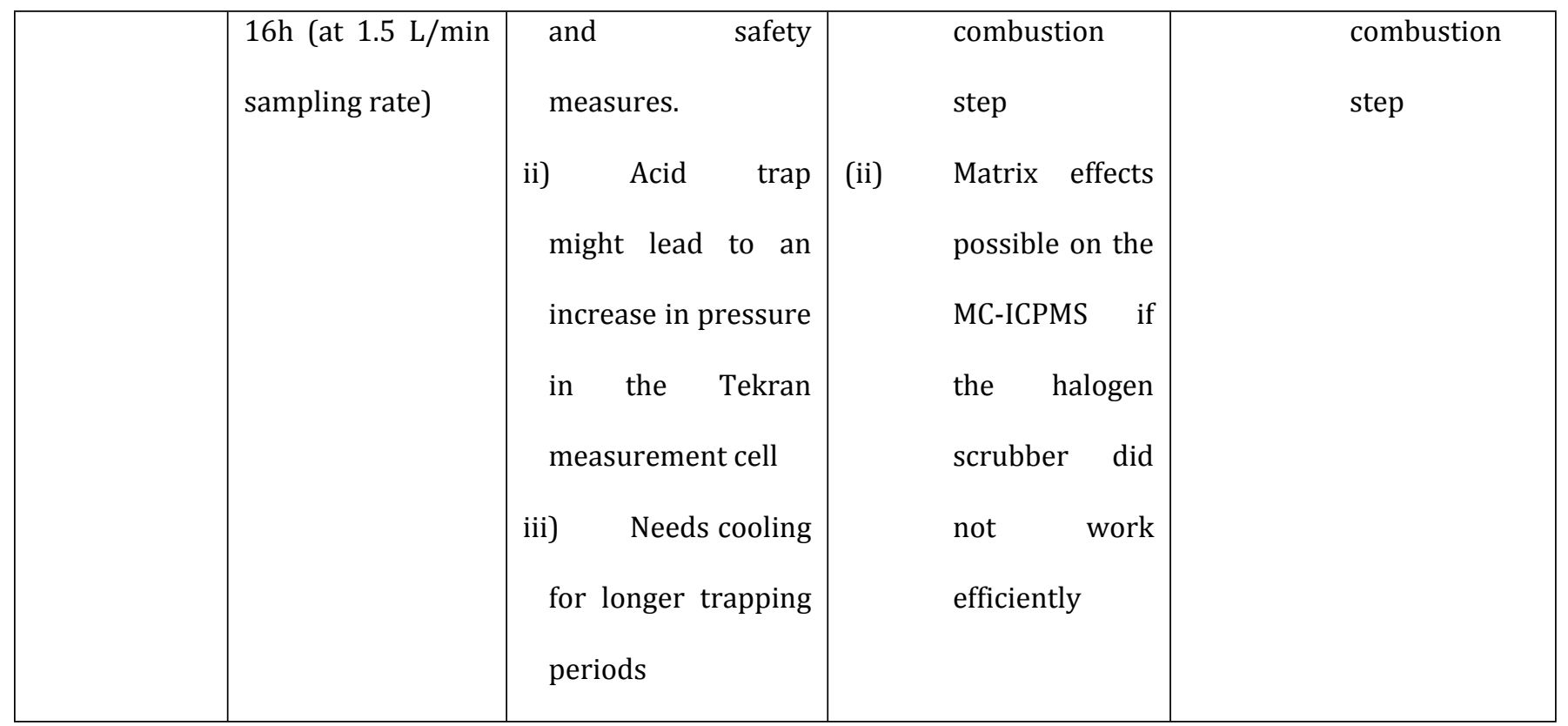

\section{Hg stable isotope analysis}

189 Hg isotope ratios were analyzed by cold vapor multi-collector inductively coupled plasma 190 mass spectrometry (MC-ICP-MS, Thermo-Finnigan Neptune) following published 191 protocols. ${ }^{24} \mathrm{Hg}$ isotope composition is reported in delta notation $(\delta)$ in per mil (\%o) by 192 referencing to the bracketed NIST $3133 \mathrm{Hg}$ standard: $\delta^{\mathrm{xxx}} \mathrm{Hg}=\left({ }^{\mathrm{xxx} / 198} \mathrm{Hg}_{\text {sample }} /{ }^{\mathrm{xxx} / 198} \mathrm{Hg}_{\mathrm{NIST} 3133}-1\right) \times 10^{3}$

194 where 'xxx' refers to measured isotope masses: 199, 200, 201, 202 and 204. MIF is reported in capital delta $(\Delta)$ notation (\%o), which is defined as the difference between the measured $\delta^{199} \mathrm{Hg}, \delta^{200} \mathrm{Hg}, \delta^{201} \mathrm{Hg}$ and $\delta^{204} \mathrm{Hg}$ and those predicted from $\delta^{202} \mathrm{Hg}$ using the

197 kinetic MDF law:

$198 \Delta^{\mathrm{xxx}} \mathrm{Hg}=\delta^{\mathrm{xxx}} \mathrm{Hg}-\beta_{\mathrm{xxx}} \mathrm{x} \delta^{202} \mathrm{Hg}$

199 where the mass-dependent scaling factor $\beta_{\mathrm{xxx}}$ is 0.252 for ${ }^{199} \mathrm{Hg}, 0.502$ for ${ }^{200} \mathrm{Hg}, 0.752$ for ${ }^{201} \mathrm{Hg}$ and 1.493 for ${ }^{204} \mathrm{Hg}$. The long-term uncertainty was evaluated by repeated 201 measurement of the ETH-Fluka Hg standard, which yielded values of $-1.45 \pm 0.19 \%$, 0.08 $\pm 0.09 \%$, $0.02 \pm 0.09 \%$, $0.03 \pm 0.09 \%$ o, $-0.03 \pm 0.2 \%$ o $(2 \sigma, \mathrm{n}=10)$ for $\delta^{202} \mathrm{Hg}, \Delta^{199} \mathrm{Hg}$, 
$203 \Delta^{200} \mathrm{Hg}, \Delta^{201} \mathrm{Hg}$ and $\Delta^{204} \mathrm{Hg}$, respectively, in agreement with the published values ${ }^{17,}{ }^{27}$. The $2042 \sigma$ uncertainties of isotope compositions for ETH-Fluka were taken as the typical analytic 205 uncertainties of isotope compositions for samples. If the $2 \sigma$ uncertainties of isotope 206 compositions for samples with multiple measurements were larger than the typical $2 \sigma$ 207 uncertainties, then the $2 \sigma$ uncertainties of samples applied.

208

209 Results \& Discussion

210 Cell vent trapping efficiency on gold in argon

Initially gold bead traps were directly connected to the $2537 \mathrm{X}$ cell vent using $1 / 8$ "

212 FEP tubing, and without presence of the $1115 \mathrm{i}$ valve module. GEM from the cell vent was 213 loaded onto the traps for time periods ranging from 1 to 70 hours. Two traps were placed 214 in series to monitor potential Hg breakthrough. Trapping recoveries were measured by 215 manual gold trap desorption with AFS detection and were variable, from $10-88 \%$, with 4 216 out of 6 recoveries considered as low, $<85 \%$ (Figure 1, Table S1). The $85 \%$ cut-off is 217 defined by the combined analysis uncertainty of sampled Hg by the Tekran ${ }^{\circledR} 2537 \mathrm{X}(15 \%$, $2182 \sigma)$, and of recovered Hg by AFS $(15 \%, 2 \sigma)$. All secondary, in-series, gold traps showed 219 signs of breakthrough and did not recover all GEM vapor lost by the first trap, suggesting 220 that the secondary traps too suffered from Hg breakthrough (Table S1). Next, we investigated gold matrix trap performance by loading 1-70 hours of cell vent GEM in argon onto the traps during regular 2537X operation (Figure 1). During 4 out 223 of 9 tests, in series gold matrix traps were used to assess breakthrough. Recoveries were 224 found to range from 38-98\%, with 3 out of 5 long loading experiments having recoveries $225<80 \%$. Again, in-series traps in $2^{\text {nd }}$ position showed significant Hg breakthrough in the 226 argon matrix (Table S1). 
Finally, gold matrix traps were loaded with controlled amounts of GEM vapor from the $2537 \mathrm{X}$ internal permeation source, also in high purity argon matrix. During 4, 7, 13 and 16 hours, 1-4 ng of permeation source GEM vapor was loaded onto the gold traps. Recoveries measured by manual trap desorption with AFS were 86-99\% (Figure 1), which is within the combined analysis uncertainty of the methods. loading times from 17-70 hours recoveries were incomplete. Overall the performance of gold traps over longer time periods at the cell vent was unexpected and likely related to the gradual passivation of the gold surface. After heating the gold traps for analysis, they performed normally, indicating no degradation of the trap. Adding a soda-lime trap prior

238 to the gold trap has been shown to increase the performance of gold traps. ${ }^{19}$ We stress

239 that our findings by no means question the use of gold traps in standard GEM vapor analyzers sampling ambient air, including the Tekran ${ }^{\circledR} 2537 \mathrm{X}$ used here, with very short

241 Hg loading times generally ranging from 2 to 10 minutes.

\section{Cell vent trapping efficiency in oxidizing solution in argon}

244 We evaluated the acid traps consisting of 40vol\% iAR oxidizing solution traps by directing 245 variable amounts (6-14 ng) of ambient GEM or 2537X permeation source GEM to the 246 traps, without presence of the $1115 \mathrm{i}$ valve manifold (Table S2). Solution Hg 247 concentrations were analyzed by CV-AFS and recoveries found to be good, in the range of $24885-104 \%$. We subsequently connected the 1115 i valve module, with its multiple tees and 249 connectors. Thirteen ambient GEM tests, loading 4-18 ng of Hg over 22-70 hours, were 250 performed with good recoveries ranging from 85-111\% (Figure 1). 
252 of Hg trapping at ambient laboratory temperature for the first four samples, $1-4$. This 253 volumetric loss did not an effect on the Hg trapping efficiency, as recoveries were 89-110 $254 \%$ for samples 1-4. Indicating soda lime traps at the solution trap outlet did not show any 255 color change suggesting that the weight loss is mostly water, rather than acid. 256 Nevertheless, a loss of $22 \%$ over 3 days can potentially become problematic for longer 257 sampling periods (7-14 day). To reduce the volume loss, we tested trapping with a manual 258 cooling system that maintained a temperature of $5-6^{\circ} \mathrm{C}$. The solution traps were placed 259 inside a polystyrene cooler, filled with ice-packs that were changed every 2 days. This system effectively reduces the volume loss by evaporation to $<6 \%$. Carry-over of GEM from the permeation source calibration cycles to sample traps 262 was tested. We connected the sample inlet of the Tekran ${ }^{\circledR} 2537 \mathrm{X}$ to a zero-air cartridge and collected cell-vent GEM for 48-72h, after routing calibration pulses of the permeation source (once every $2 \mathrm{~h}$ ) to a separate trap. We found that less than $2 \%(\mathrm{n}=2)$ of perm-cell 265 Hg was transferred to subsequent samples and conclude that carry-over from the 266 permeation source to the following sample did not cause any significant bias in ISO-GEM 267 measurements.

We tested the $\mathrm{Hg}$ from the permeation cell calibration unit as internal standard for

269 Hg stable isotope measurements by trapping the calibration cycle GEM pulse on a 270 dedicated valve position and found very consistent $\delta^{202} \mathrm{Hg}$ and $\Delta^{199} \mathrm{Hg}$ values, over 271 multiple $(n=5)$ test days (Figure 2). Please note that we tested only one instrument and 272 that the uniformity of the permeation source $\mathrm{Hg}$ isotope composition from other 273 instruments has to be confirmed. In summary, acid traps based on 40\%-iAR provide a good cell vent trapping with 275 high recovery, low break-through and low blanks. A major advantage is the direct 
measurement of the (2x diluted) acid on the MC-ICPMS without further pre-enrichment steps. Acid traps however have the drawback of acid being handled in the field and during shipment which can cause higher costs/efforts for logistics and personal safety.

\section{trapping efficiency on activated carbon in ambient air}

We evaluated the efficiency of iodine activated carbon (I-AC) and sulfur-impregnated activated carbon (HGR-AC) traps by pumping ambient air over the traps for prolonged periods (48 - 62 days) at a flow rate of $0.3 \mathrm{~L} / \mathrm{min}$. We expect a similar performance of IAC and HGR-AC traps in $80 \mathrm{~mL} / \mathrm{min}$ Argon at the cell vent of the Tekran ${ }^{\circledR} 2532 \mathrm{X}$ analyzer compared to the 4 times higher flowrate of ambient air tested here.

Breakthrough of I-AC and HGR-AC traps was measured after two months of continuous sampling of at $0.3 \mathrm{~L} / \mathrm{min}$, by connecting the traps to a Tekran ${ }^{\circledR} 2537 \mathrm{X}$ analyzer and pumping ambient air over the traps at $1 \mathrm{~L} / \mathrm{min}$. For both carbon traps, I-AC and HGR$\mathrm{AC}$ the $\mathrm{Hg}$ concentration measured after the trap was below the detection limit $(<0.1$ $\mathrm{ng} / \mathrm{m}^{3}$ ), indicating that there was no measurable breakthrough.

Both, I-AC and HGR-AC showed good recoveries, however the reproducibility for HGR-AC ( $94 \pm 4 \%, \mathrm{n}=4)$ was better than for I-AC (97 \% $\pm 39 \%, \mathrm{n}=10)$ (including data from Ref. ${ }^{10}$ ). The blank for I-AC was $2.6 \pm 0.8 \mathrm{ng} / \mathrm{g}$ and for HGR-AC was $0.16 \pm 0.06 \mathrm{ng} / \mathrm{g}$. Considering the different amounts of powder used for the traps, this resulted in absolute Hg amounts of $0.32 \mathrm{ng}$ and $0.06 \mathrm{ng}$ per trap for I-AC and HGR-AC, respectively.

Based on our experience, IC powder is more challenging to combust as it liberates large amounts of volatile iodine compounds that need to be removed from the combustion carrier gas using halogen traps. If not, the iodine will form strong Hg-iodide complexes in the oxidizing solution trap, which may affect $\mathrm{Hg}$ isotope analyses by an incomplete reduction of $\mathrm{Hg}(\mathrm{II})$-iodide during cold-vapor generation. Sulfur generates gaseous $\mathrm{SO}_{2}$, 
301 which partly becomes sulfuric acid in the oxidizing solution trap and does not interfere 302 later on with $\mathrm{Hg}(\mathrm{II})$ reduction by $\mathrm{Sn}(\mathrm{II})$.

In summary, we found both 40vol\%iAR oxidizing solution traps and activated 304 carbon based I-AC and HGR-AC traps to recover GEM quantitatively at the 2537X cell vent 305 over prolonged periods of sampling. The three types of traps have different advantages 306 and disadvantages (Table 1). Solution traps require no further processing, other than 307 dilution to 20vol\%iAR, before direct Hg isotope measurement. The solution traps need to 308 be cooled however, to avoid evaporation of the acidic solution, and shipping acidic 309 solutions from sampling site to laboratory requires strict safety precautions. Handling 310 and shipping of I-AC and HGR-AC traps is more convenient, however they require further 311 processing by dual tube furnace combustion methods to recover trapped Hg for isotopic 312 analysis. The choice of trap type has to be made on an individual basis depending on the research question and logistical settings (e.g. long-term vs. short-term campaign).

\section{ISO-GEM multi-valve manifold configuration}

The Tekran ${ }^{\circledR} 1115 \mathrm{i}$ multi-valve manifold we tested is equipped with 5 small valves and 3 large valves (Figure S2). The small valves can be connected in a parallel or tree configuration to the 2537X cell vent (Figure S3) and guide GEM vapor to 4 or 5 different GEM isotope traps. The three large valves can be configured either at the 2537X inlet to sample different physical sources of Hg (outside/inside; night/day; etc.) or be used at the cell vent for additional GEM trapping capacity.

One GEM isotope trap is exclusively dedicated for the mercury coming from the

323 permeation source in the aim to not have a contribution to ambient air samples and bias 324 in the $\mathrm{Hg}$ isotopic ratios. Permeation source GEM also serves as internal $\mathrm{Hg}$ isotope 325 standard. 
The $1115 \mathrm{i}$ multi-valve manifold is directly programmed by the intuitive plugin developed by Tekran ${ }^{\circledR}$ (Figure S4). This plugin allows to program the $1115 \mathrm{i}$ according to different criteria chosen by the user. For each event (e.g. inside building during nighttime) a series of valve positions (open vs. closed) are defined, determining which air mass is analyzed (e.g. inside vs. outside) and directing the GEM to a designated isotope trap after analysis (Figure 3A and Figure S5 - S7). This allows for the automated sampling of air collected under pre-defined conditions (e.g. time, location, Hg amount). The plugin monitors the status and timing in the programming and actuates the solenoid valves according to the program synchronized with the measurement cycle of the 2537X. The user will also assign any programmed event-flags in the sample data recorded by the 2537X. These flags provide positive indication of $1115 \mathrm{i}$ operations performed during each sampling period and allow to calculate trapping yields on individual traps. The following events can be programmed by the Tekran ${ }^{\circledR} 1115 \mathrm{i}$ plugin.

339 (i) A/B-cycling. This event switches the valve position every A/B cycle (usually $10 \mathrm{~min}$ ) between customized valve positions, to e.g. quasi-simultaneously measuring and sampling at different locations (e.g. gradient, inside/outside, etc.) (Figure S5). period on separate ports (valves) (Figure S6).

(iii) GEM threshold event. This event will be a function of the Hg concentration measured by the $2537 \mathrm{X}$. In the plugin we specify a threshold of GEM concentration allowing to switch a valve and load GEM to a different trap. Any GEM concentration higher than the specified value will trigger a set of valve state and flag (Figure 3A). 
(iv) ADC trigger input event. The ISO-GEM application can be configured with an external trigger from an auxiliary sensor (e.g. $\mathrm{O}_{3}$ or $\mathrm{CO}$ analyzers) or program. An analog signal (up to $5 \mathrm{~V}$ ) can be sent by an external source to the $1115 \mathrm{i}$ plugin and the valve positions are switched when a certain pre-defined threshold is reached. Note that we did not have time to test this feature. (Figure S7)

\section{ISO-GEM application to building emissions}

In an exploratory study we used ISO-GEM to investigate the GEM emission from a building surface and its effect on spatial GEM concentrations. In different settings we programmed ISO-GEM to quasi-simultaneously measure inside and outside the building $(\mathrm{i}-\mathrm{A} / \mathrm{B}$ cycling), to distinguish between day and night (ii - time event) and to distinguish between GEM concentration levels (arbitrary GEM threshold: $>3 \mathrm{ng} / \mathrm{m}^{3}$ and $<3 \mathrm{ng} / \mathrm{m}^{3}$, iii $-\mathrm{Hg}$ amount event) (Results in Table S3). Furthermore, we sampled GEM at two different

364 locations outside the GET laboratory building, close to the building surface (wall-inlet, 1.2 $365 \mathrm{~m}$ above ground) and $3 \mathrm{~m}$ away from the building (free-inlet, $2 \mathrm{~m}$ above ground) (Figure 4A). The building wall consists of powder coated aluminum siding. concentrations (3.8 $\pm 1.8 \mathrm{ng} / \mathrm{m}^{3}$, mean and $1 \sigma$ on $1 \mathrm{~h}$ means) and $\mathrm{Hg}$ stable isotope signatures showed negative $\delta^{202} \mathrm{Hg}$ values $(-1.26 \pm 0.41 \%, 1 \mathrm{sd}, \mathrm{n}=16)$ and circum-zero $\Delta^{199} \mathrm{Hg}$ values $(-0.05 \pm 0.10 \%$ o, $1 \mathrm{sd}, \mathrm{n}=16)$. GEM concentrations measured at the free inlet

371 of $1.5 \pm 0.4 \mathrm{ng} / \mathrm{m}^{3}$ (mean and $1 \sigma$ on $1 \mathrm{~h}$ means) were similar to Northern Hemispheric

372 background levels of $\sim 1.5 \mathrm{ng} / \mathrm{m}^{3} \cdot{ }^{21} \mathrm{Hg}$ stable isotope signatures measured at the free 373 inlet $\left(\delta^{202} \mathrm{Hg}=0.77 \% 0 \pm 0.08 \%\right.$, $\Delta^{199} \mathrm{Hg}=-0.22 \%$ $\pm 0.04 \%$, mean and $\left.1 \sigma, \mathrm{n}=7\right)$ agreed 374 well with measurements reported for background sites in France and the US $\left(\delta^{202} \mathrm{Hg}=\right.$ $3750.53 \%$ $\% 0.37 \% 0, \Delta^{199} \mathrm{Hg}=-0.22 \%$ $\pm 0.05 \%$, mean and $1 \sigma, \mathrm{n}=59$ )(Figure 2$) .5-7,10$ The 
similar $\mathrm{Hg}$ isotope signatures and $\mathrm{Hg}$ concentrations measured at the free inlet in suburban Toulouse compared to Northern Hemispheric background sites suggests that GEM was dominated by long-range transport background GEM and that the contribution from local anthropogenic sources and local building emission was minor.

Using the time event (ii) function, we collected the air at the wall inlet sampled during daytime and nighttime on two different traps. Daytime air was characterized by higher GEM concentrations $\left(3.5 \pm 0.8 \mathrm{ng} / \mathrm{m}^{3}, \mathrm{n}=3\right)$ than nighttime air $\left(2.6 \pm 0.3 \mathrm{ng} / \mathrm{m}^{3}\right.$, $\mathrm{n}=3$ ). The higher GEM concentration of daytime air was concomitant with more negative $\delta^{202} \mathrm{Hg}$ values $(-1.82 \% 0 \pm 0.37 \%, \mathrm{n}=3)$ than nighttime air $(-1.36 \%$ \% $0.17 \% 0, \mathrm{n}=3)$. $\Delta^{199} \mathrm{Hg}$ values were similar between daytime $(-0.03 \%$. $0.09 \%, \mathrm{n}=3)$ and nighttime air $(-0.03 \%$ \% $0.11 \%, \mathrm{n}=3)$. The higher GEM concentrations during daytime observed at the wall inlet is opposite to observations from other urban sites, where highest GEM concentrations were observed in the early morning when the nocturnal boundary layer was most stable. ${ }^{28,29}$ This suggests that the high GEM concentrations measured at the wall inlet were affected by local emissions from photo-chemical or temperature related processes (see discussion below).

Using the GEM threshold event (iii) function we separated the outside air of the wall inlet on two different traps using a threshold of $3 \mathrm{ng} / \mathrm{m}^{3}$ (Figure 3 ). $\delta^{202} \mathrm{Hg}$ was more negative for the trap with higher concentration $\left(>3 \mathrm{ng} / \mathrm{m}^{3}\right.$, mean GEM $=3.9 \mathrm{ng} / \mathrm{m}^{3}, \delta^{202} \mathrm{Hg}$ $=-1.54 \% 0)$ compared to the trap that collected lower GEM $\left(<3 \mathrm{ng} / \mathrm{m}^{3}\right.$, mean GEM $=2.8$ $\mathrm{ng} / \mathrm{m}^{3}, \delta^{202} \mathrm{Hg}=-1.19 \%$ )

Combining all wall and free outside measurements, we found a strong linear correlation between the $\delta^{202} \mathrm{Hg}$ signature and the $\mathrm{Hg}$ concentration of GEM expressed as $1 / \mathrm{Hg}\left(\mathrm{R}^{2}=0.91, \mathrm{p}<0.001\right.$, Figure $\left.5 \mathrm{C}\right)$ as well as between $\Delta^{199} \mathrm{Hg}$ and $1 / \mathrm{Hg}\left(\mathrm{R}^{2}=0.57\right.$, $\mathrm{p}<0.001$, Figure 5D). This strong correlation suggests that outdoors GEM can be explained 
401 by two distinct sources, GEM emission from the local building and GEM from background 402 air. The high variability of the GEM concentration at the wall-inlet (Figure 4 B) and the 403 extent of mixing between GEM emission from the building with GEM from background air 404 is likely controlled by the turbulence of air in proximity to the building.

Mercury concentrations in buildings can be highly elevated compared to outdoor ambient air concentrations. ${ }^{30}$ It has been suggested that $10 \%$ of the households in the United States exhibit indoor GEM concentrations exceeding the U.S. reference concentration of $300 \mathrm{ng} \mathrm{m}^{-3} \cdot{ }^{30} \mathrm{Hg}$ has been used as biocide in paint in between 1950 and 1990 and was thus intentionally employed in buildings. ${ }^{31}$ A second source of $\mathrm{Hg}$ in buildings are micro-spills through the accidental release from products containing $\mathrm{Hg}$, such as e.g. thermometers or fluorescent light-bulbs. ${ }^{30}$ Using the A/B-cycle (i) sampling

412 scheme we measured the GEM concentration quasi-simultaneously inside and outside the 413 GET laboratory building in Toulouse. The GEM concentration inside the building was 3.61 $414 \mathrm{ng} / \mathrm{m}^{3}$, whereas the outside concentration was $2.45 \mathrm{ng} / \mathrm{m}^{3}$ during the same period. Given 415 that the concentration difference was relatively small $\left(1.2 \mathrm{ng} / \mathrm{m}^{3}\right)$ and all the windows of 416 the building were permanently closed, we assume that emission from inside the building 417 contributed insignificantly to the elevated GEM concentrations measured at the wall inlet. Elevated GEM concentrations outside buildings have been reported for several 419 urban areas with e.g. 2.7 to $3.8 \mathrm{ng} / \mathrm{m}^{3}$ in New York, ${ }^{32} 2.0 \mathrm{ng} / \mathrm{m}^{3}$ in Windsor, ON close to Detroit, $^{33} 1.9 \mathrm{ng} / \mathrm{m}^{3}$ in Toronto ${ }^{34}$ and $9.7 \mathrm{ng} / \mathrm{m}^{3}$ in Guiyang, China. ${ }^{35}$ Carpi and Chen 421 suggested that elevated GEM concentrations in urban areas were related to re-emission 422 of GEM from building and other urban surfaces. ${ }^{32}$ They suggest that the GEM originates 423 from photochemical reduction of divalent $\mathrm{Hg}$ that has previously been deposited through 424 dry deposition. ${ }^{32}$ Preliminary measurements of divalent $\mathrm{Hg}$ in precipitation at the 425 Toulouse site (data not reported here in detail; $\Delta^{200} \mathrm{Hg}=0.12 \% \pm 0.11 \%$, $\mathrm{n}=4$ ) are in 
agreement with precipitation data measured elsewhere. ${ }^{4,7,11,36,37}$ The $\Delta^{200} \mathrm{Hg}$ values of

427 GEM samples at the wall inlet $(-0.04 \% \pm 0.06 \%, n=16)$ was very similar to that of GEM

428 measured at the free inlet $(-0.06 \%$ m $\pm 0.04 \%, \mathrm{n}=7)$ or at remote sites $(-0.04 \% 0 \pm 0.03$

$429 \%$, $n=39$ ). 5,6, 7,5, 10 Aluminum, the material of the building facade, can form an amalgam

430 with $\mathrm{Hg}^{38} \mathrm{Hg}$ in the building wall may originate from dry deposition of GEM from the

431 atmosphere during colder winter months (i.e. through amalgamation by the aluminum

432 building material) rather than from dry deposition of divalent $\mathrm{Hg}$ which would be expected to exhibit positive $\Delta^{200} \mathrm{Hg}$ anomalies. With the data presented here we cannot exclude the presence of residual $\mathrm{Hg}$ from the production process of the building material and a contribution to the re-emission observed. There are no experimental studies investigating Hg stable isotope fractionation during volatilization of GEM from aluminum amalgam, however the isotopic signatures at the wall inlet agree with the volatilization of 438 GEM from liquid $\mathrm{Hg}$, with negative $\delta^{202} \mathrm{Hg}$ and small positive $\Delta^{199} \mathrm{Hg}$ in the vapor phase. ${ }^{39}$, $439{ }^{40}$ GEM concentrations at the wall inlet were positively correlated with the ambient air 440 temperature $\left(\mathrm{R}^{2}=0.21, \mathrm{p}<0.001\right.$, Figure $\left.\mathrm{S} 8\right)$ in agreement with previous findings, ${ }^{32}$ 441 suggesting that the re-emission flux was favored by higher temperature or solar 442 irradiation. The exploratory results of the ISO-GEM application illustrate the potential of smart 444 automated sampling strategies based on pre-defined criteria (e.g. time, location, internal 445 (GEM concentration) and triggers from external sensors $\left(\mathrm{O}^{3}\right.$, wind direction) $)$ to 446 maximize the information of the $\mathrm{Hg}$ stable $\mathrm{Hg}$ isotope finger printing tool. At the same 447 time the elevated GEM concentration and distinct Hg stable isotope signatures measured 448 at the wall inlet close to the building surface illustrate how air can be affected very locally 449 by building emissions. This has important implications for atmospheric GEM monitoring 
450 stations, where sample inlets have to be placed carefully in order to avoid measurement

451 bias from local building emission. ${ }^{41,42}$

452

\section{Financial Interests:}

454 The automated multi-valve module (1115i) at the center of the ISO-GEM application is

455 commercially available from the Tekran ${ }^{\circledR}$ Instruments Corporation. We would like to 456 mention that the conceptual ISO-GEM idea can be implemented by a custom-made 457 instrumentation and control software without purchase of the $1115 \mathrm{i}$ module.

458

459 Acknowledgments:

460 This work was supported by ERC-2015-PoC_665482 grant from the European Research 461 Council to JES, and by the Tekran ${ }^{\circledR}$ Instruments Corp. MJ received funding through the 462 H2020 Marie Sklodowska-Curie grant agreement 657195 and Swiss National Science 463 Foundation grant PZ00P2_174101.

\section{Supporting Information:}

466 Additional figures, and tables. The Supporting Information is available free of charge on 467 the ACS Publications website at DOI: 


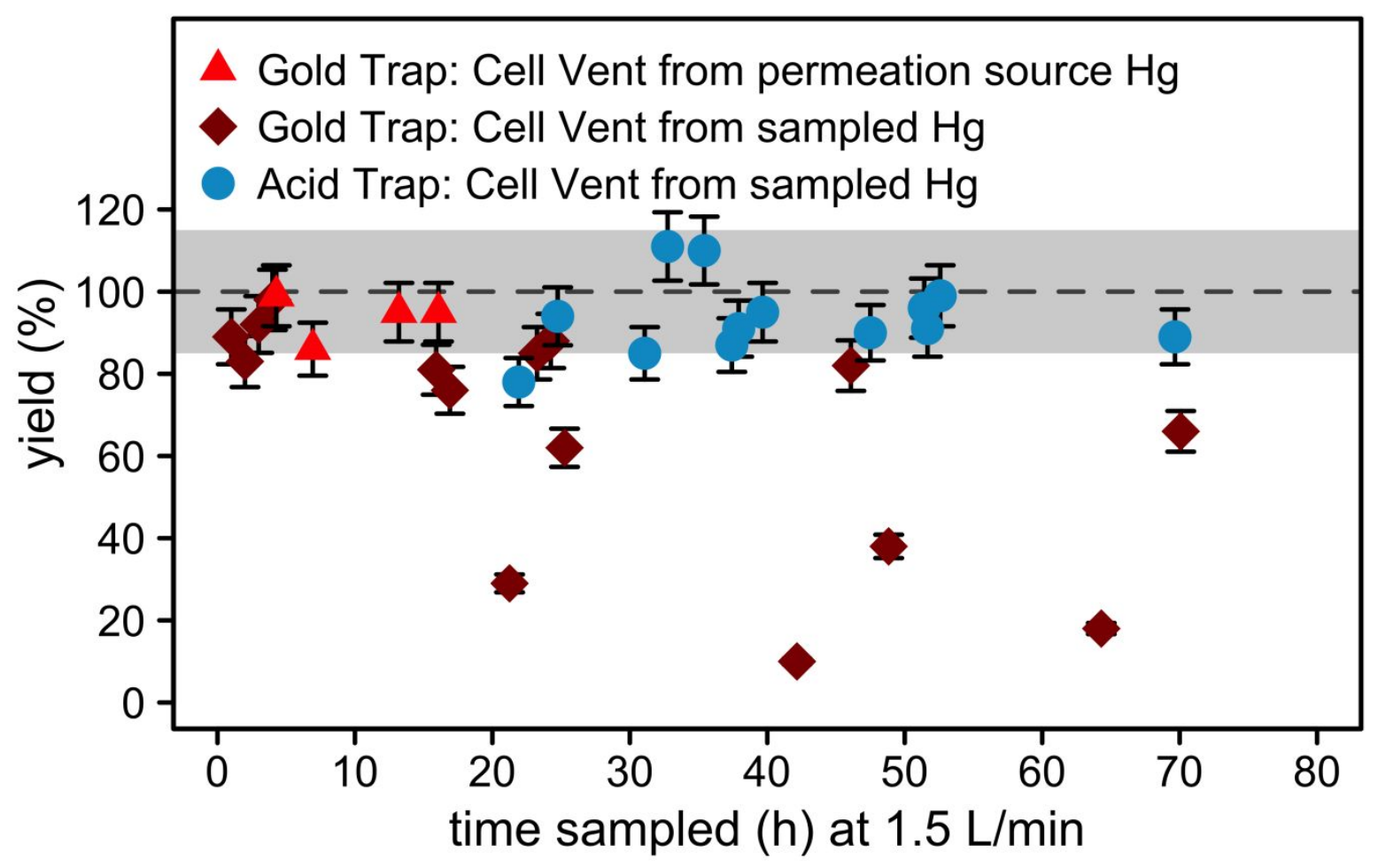

475

476 Figure 1: Sampling yields (\%) of GEM recovered in high purity argon by different trap 477 methods at the outlet of a Tekran ${ }^{\circledR} 2537 \mathrm{X}$ analyzer relative to Tekran ${ }^{\circledR}$ GEM concentration 478 measurements. GEM from ambient air was recovered at the cell vent by gold-traps (red 479 diamonds) and acid-traps (blue circles). GEM from the permeation source recovered from 480 the cell vent in argon with gold-traps is shown as red triangles. The error bars represent $4817.5 \%(1 \sigma)$ uncertainty of combined AFS measurements. The dashed line represents 100 $482 \%$ sampling yield and the shaded area represent the interval of $85 \%-115 \%$ yield that is 483 expected acceptable for Hg stable isotope measurements. 


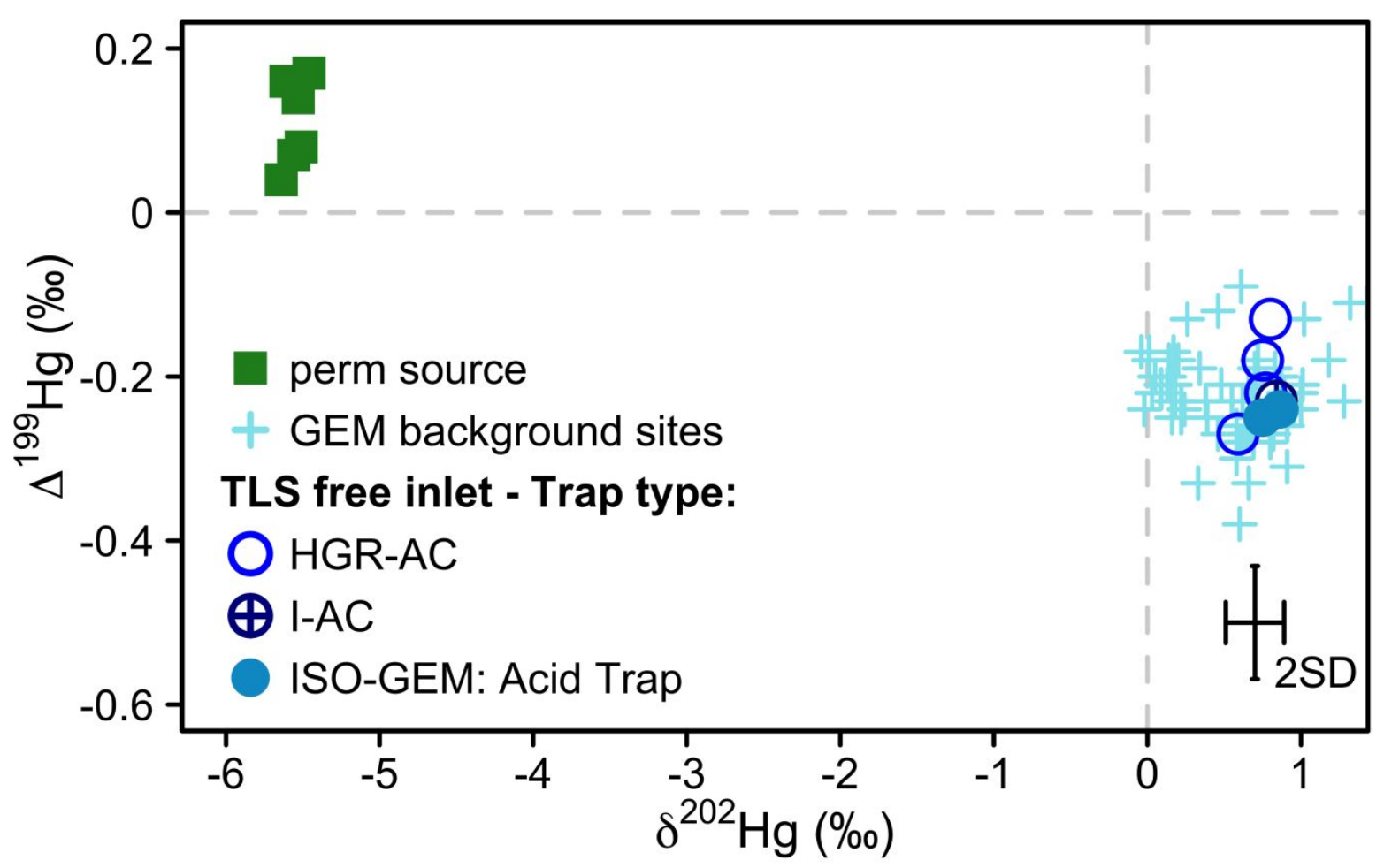

485

486 Figure 2: Mass-dependent $\left(\delta^{202} \mathrm{Hg}\right)$ vs. mass-independent $\left(\Delta^{199} \mathrm{Hg}\right) \mathrm{Hg}$ isotope signatures 487 of GEM measured by different trap types at the free inlet in Toulouse, France. For 488 comparison, GEM measurements at remote sites ${ }^{5,6,7,5,10}$ are shown as blue crosses. The 489 isotope signatures of GEM supplied by the internal permeation source of the Tekran ${ }^{\circledR}$ 490 2537X collected with an acid-trap (green squares) serves as internal isotope standard for 491 the ISO-GEM system. The error bars represent the 2 SD of replicate inhouse standard 492 measurements. 


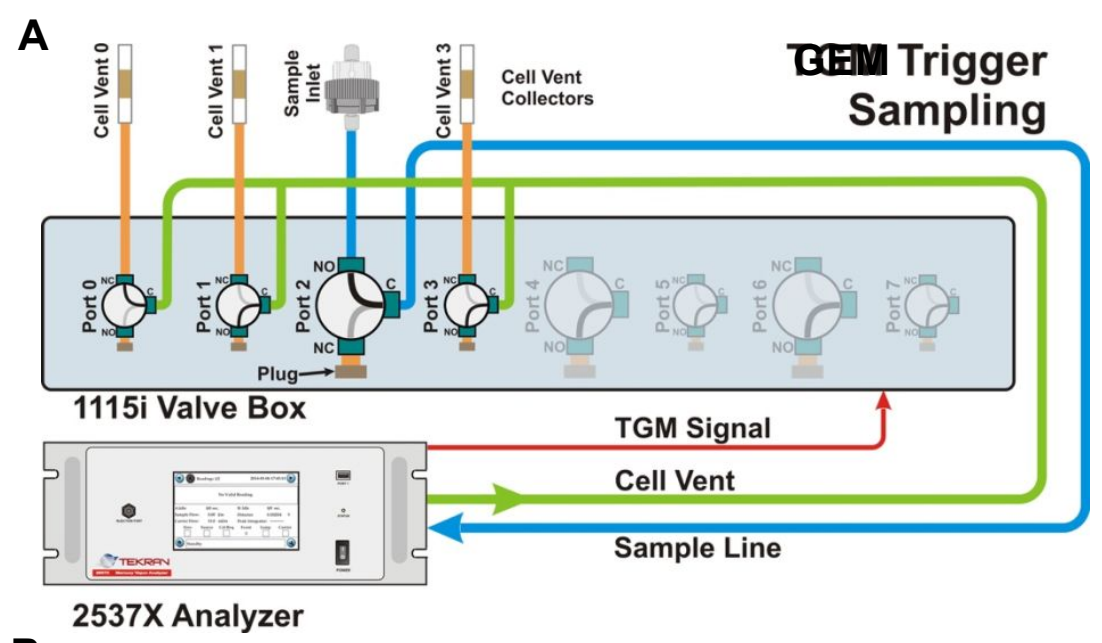

B

\begin{tabular}{l|c|c|c|c|c|} 
Event & Port 0 & Port 1 & Port 2 & Port 3 & Flag \\
\hline GEM $<3 \mathrm{ng} / \mathrm{m}^{3}$ & $\checkmark$ & X & X & X & 1 \\
GEM $>3 \mathrm{ng} / \mathrm{m}^{3}$ & X & $\checkmark$ & X & X & 2 \\
Permeation source calibration & X & X & X & $\checkmark$ & 0
\end{tabular}

C

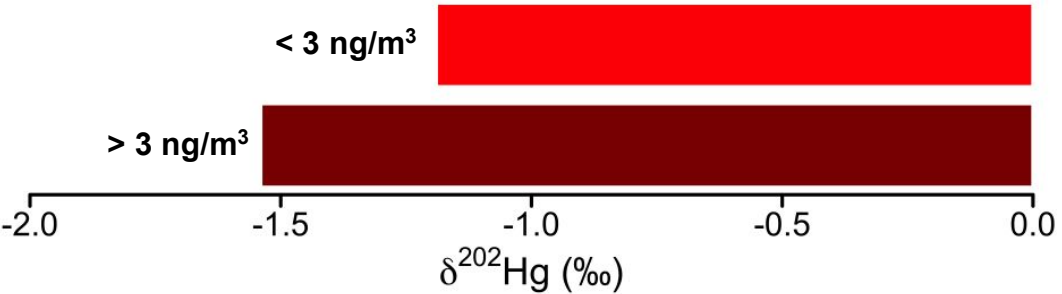

495 Figure 3: A: ISO-GEM configuration with a GEM threshold event. B: Valve configuration of

496 GEM threshold event. When GEM $<3 \mathrm{ng} \mathrm{m}^{-3}$, analyzed GEM at the cell vent is directed to

497 'port 0' (and trap 0). When GEM $>3 \mathrm{ng} \mathrm{m}^{-3}$, analyzed GEM at the cell vent is directed to

498 'port 1' (and trap 1). C: $\delta^{202} \mathrm{Hg}$ of GEM separated by concentration criteria $\left(<3 \mathrm{ng} \mathrm{m}^{-3},>3\right.$

$\left.499 \mathrm{ng} \mathrm{m}^{-3}\right)$. 
508

509

510

511

512

513

514

515

516

517

518

519

520

521

522

523

524

525

A
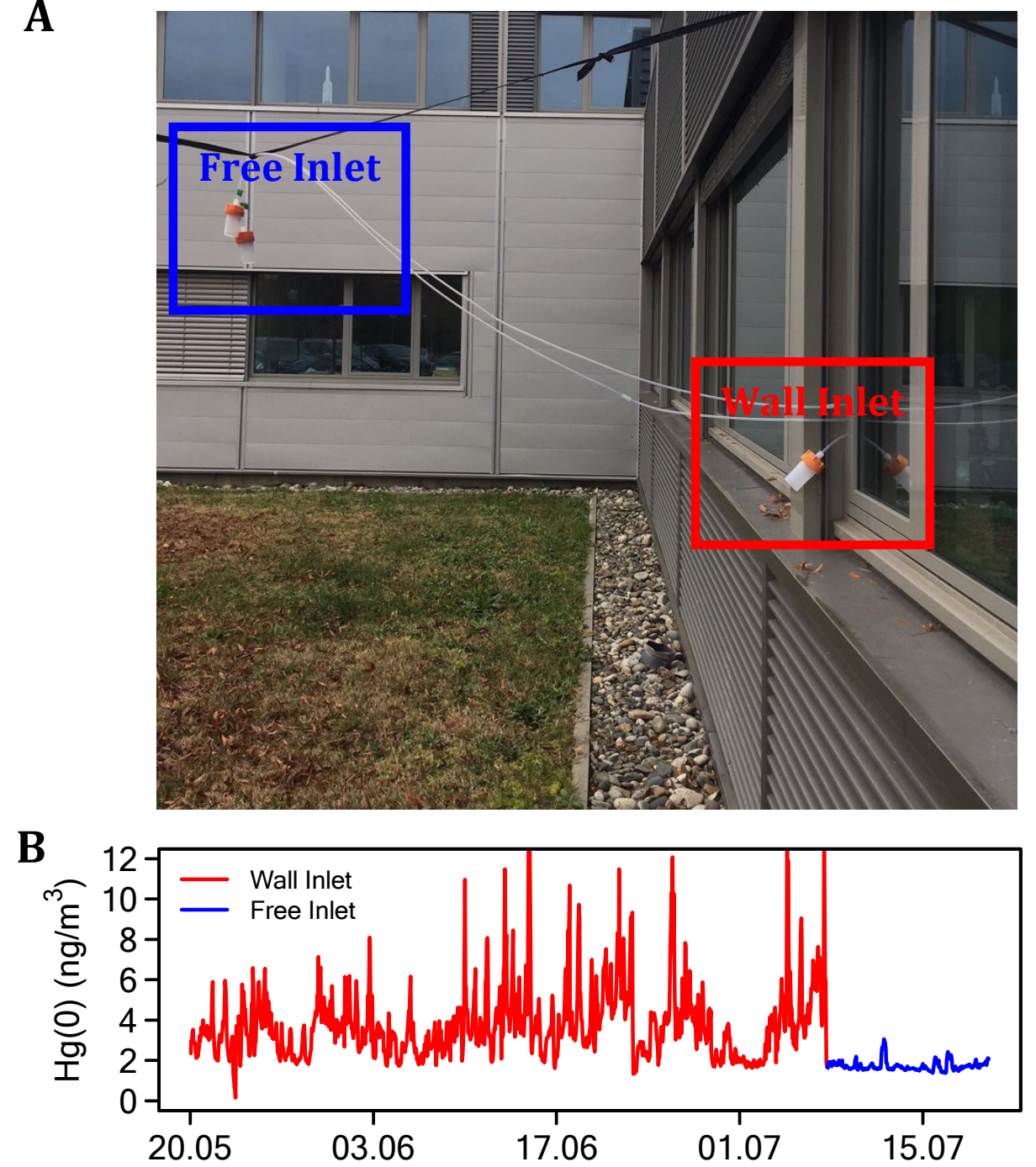

C

526

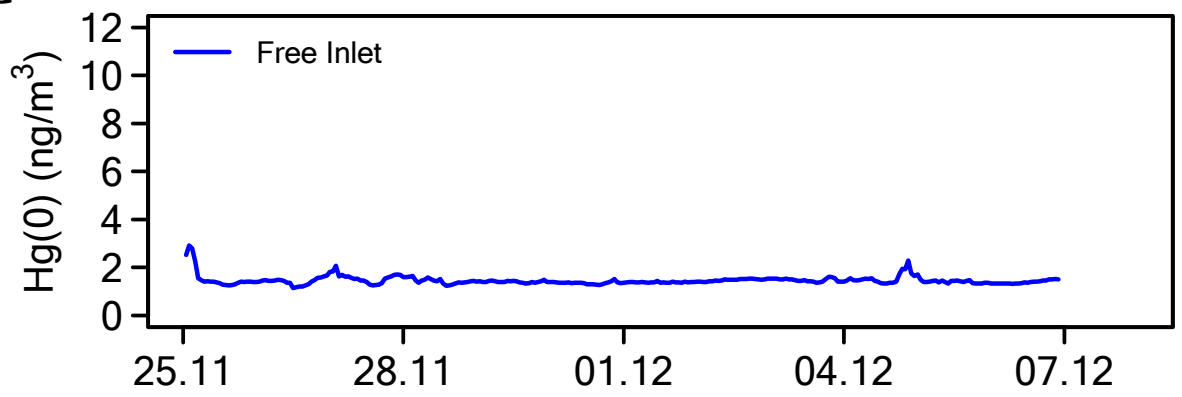

529 Figure 4: A) Setup of air sampling inlets with the wall inlet (red) and free inlet (blue) B)

530 GEM concentration measured from both inlets during summer 2017 C) GEM

531 concentration measured during fall 2017. 
A

534

535

536

537

538

539

540

541

542

543

544

C

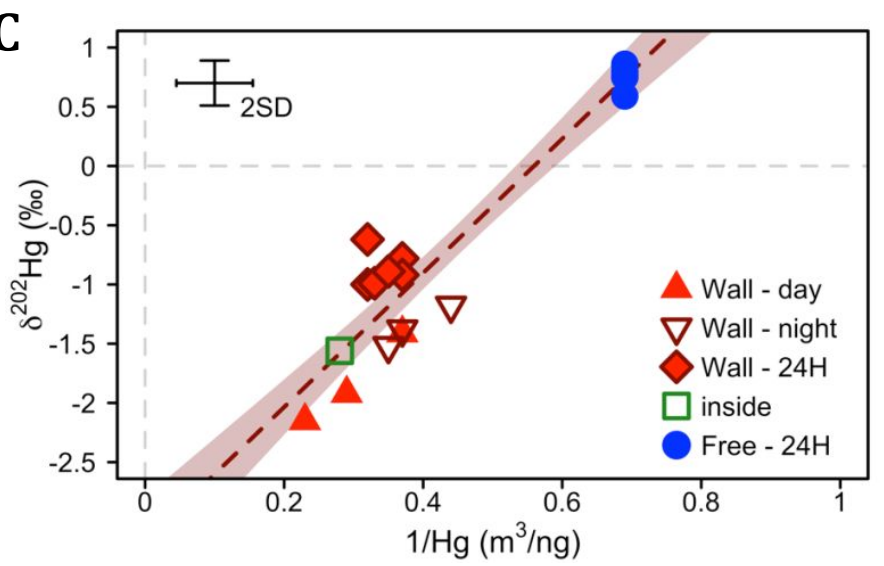

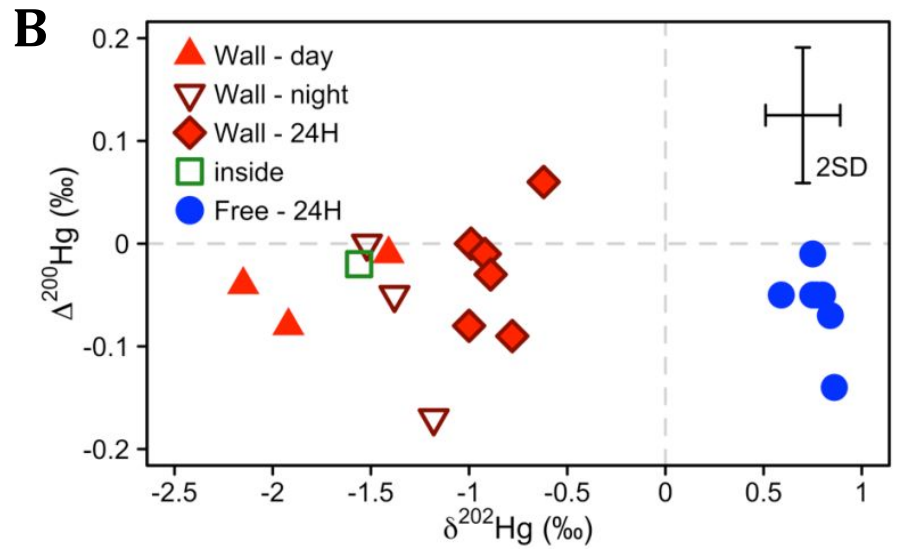

D

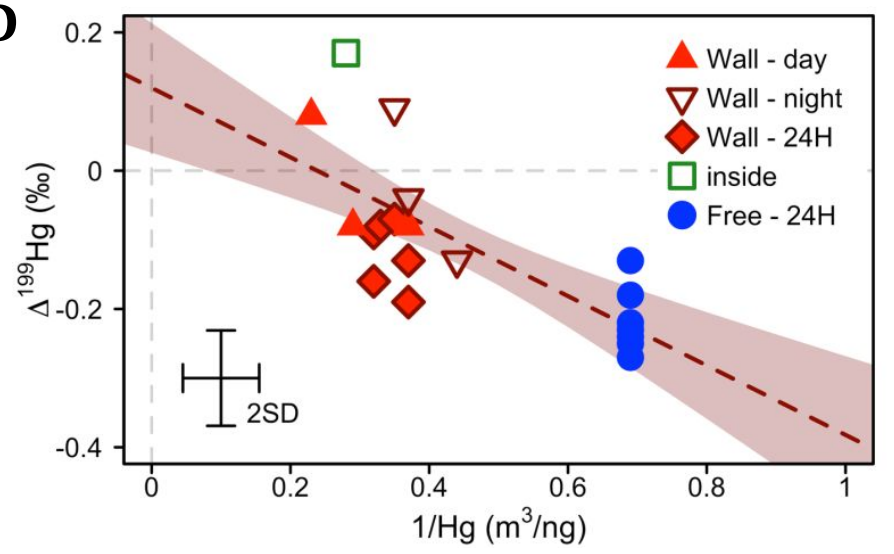

Figure 5: Hg isotope signature of GEM measured at a free inlet (blue circles) and a wall inlet (red triangles and diamonds) outside a laboratory building and inside the laboratory

548 (green squares) in urban Toulouse, France A) $\Delta^{199} \mathrm{Hg}$ vs. $\left.\delta^{202} \mathrm{Hg}, \mathbf{B}\right) \Delta^{200} \mathrm{Hg}$ vs. $\delta^{202} \mathrm{Hg}, \mathbf{C}$ ) $549 \delta^{202} \mathrm{Hg}$ vs. $1 / \mathrm{Hg}$, and D) $\Delta^{199} \mathrm{Hg}$ vs. $1 / \mathrm{Hg} .$. The dashed lines represent the linear regression and the shaded area represents the 95\% confidence interval of the linear regression. The error bars represent the 2 SD of replicate inhouse standard measurements. 


\section{Atmospheric mercury isotope fingerprinting: ISO-GEM}

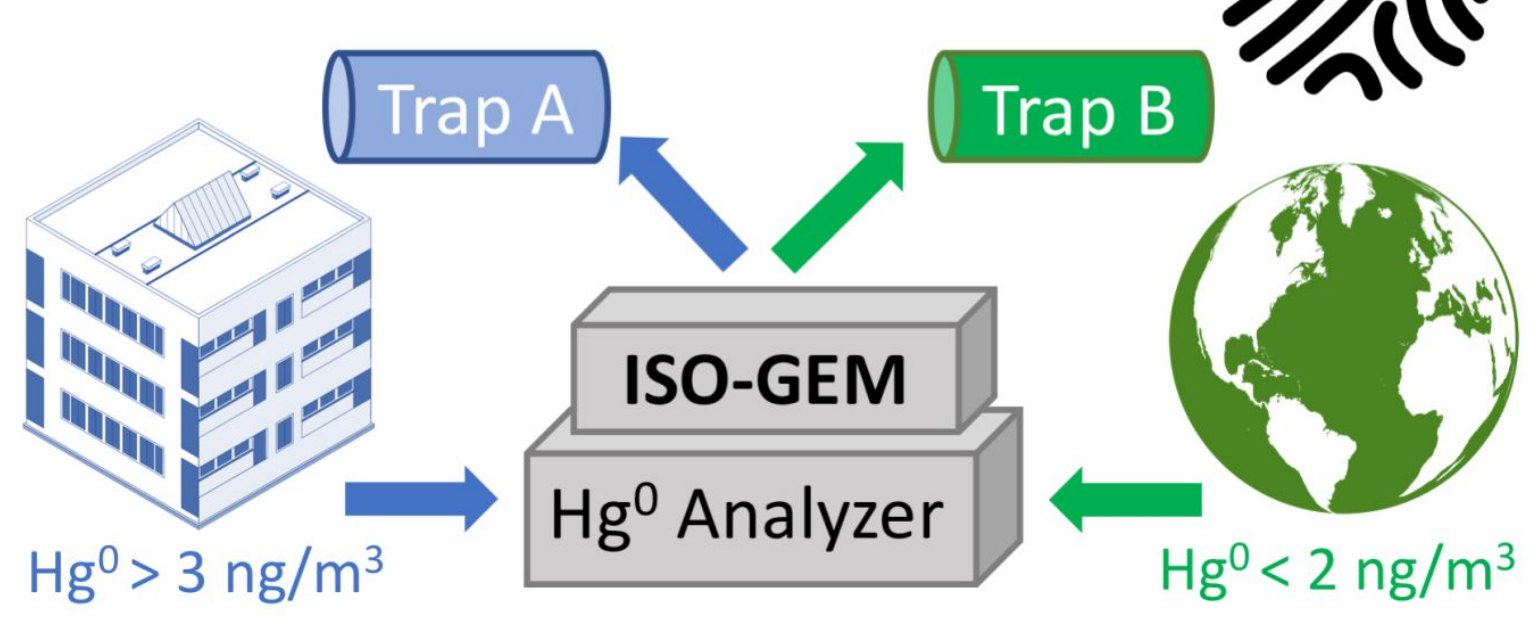

559

560

561

562

563

564

565

566

567

568

569

570

571

572

573

574

575

576

577

578

579

580

581

582

583

584

585

586

587 
1. Driscoll, C. T.; Mason, R. P.; Chan, H. M.; Jacob, D. J.; Pirrone, N., Mercury as a global pollutant: sources, pathways, and effects. Environ. Sci. Technol. 2013, 47, (10), 4967-4983.

2. Obrist, D.; Kirk, J. L.; Zhang, L.; Sunderland, E. M.; Jiskra, M.; Selin, N. E., A review of global environmental mercury processes in response to human and natural perturbations: Changes of emissions, climate, and land use. Ambio 2018, 47, (2),

3. Jiskra, M.; Sonke, J. E.; Obrist, D.; Bieser, J.; Ebinghaus, R.; Myhre, C. L.; Pfaffhuber, 116-140.

4. Gratz, L. E.; Keeler, G. J.; Blum, J. D.; Sherman, L. S., Isotopic composition and 603 fractionation of mercury in great lakes precipitation and ambient air. Environ. Sci. Technol. 2010, 44, (20), 7764-7770.

5. $\quad$ Demers, J. D.; Sherman, L. S.; Blum, J. D.; Marsik, F. J.; Dvonch, J. T., Coupling atmospheric mercury isotope ratios and meteorology to identify sources of mercury impacting a coastal urban-industrial region near Pensacola, Florida, USA. Global Biogeochem. Cycles 2015, 29, (10), 1689-1705.

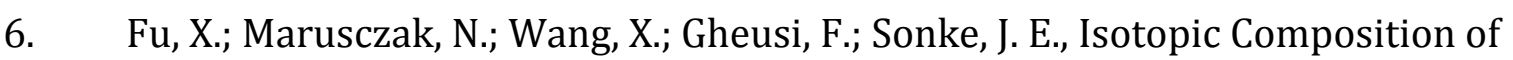
Gaseous Elemental Mercury in the Free Troposphere of the Pic du Midi

7. Enrico, M.; Roux, G. L.; Marusczak, N.; Heimburger, L. E.; Claustres, A.; Fu, X.; Sun, Wang, Z.; Shang, L.; Sommar, J.; Sonke, J. E.; Maurice, L.; Guinot, B.; Feng, X., R.; Sonke, J. E., Atmospheric mercury transfer to peat bogs dominated by gaseous elemental mercury dry deposition. Environ Sci Technol 2016, 50, (5), 2405-12. Isotopic Composition of Atmospheric Mercury in China: New Evidence for Sources and Transformation Processes in Air and in Vegetation. Environ Sci Technol 2016, 50, (17), 9262-9. 
620 9. Yamakawa, A.; Moriya, K.; Yoshinaga, J., Determination of isotopic composition of 621 atmospheric mercury in urban-industrial and coastal regions of Chiba, Japan, using cold vapor multicollector inductively coupled plasma mass spectrometry. Chemical Geology 2017, 448, 84-92.

10. Obrist, D.; Agnan, Y.; Jiskra, M.; Olson, C. L.; Colegrove, D. P.; Hueber, J.; Moore, C.

11. Demers, J. D.; Blum, J. D.; Zak, D. R., Mercury isotopes in a forested ecosystem: Implications for air-surface exchange dynamics and the global mercury cycle. Global Biogeochem. Cycles 2013, 27, (1), 222-238.

12. Fu, X.; Yang, X.; Tan, Q.; Ming, L.; Lin, T.; Lin, C.-J.; Li, X.; Feng, X., Isotopic Composition of Gaseous Elemental Mercury in the Marine Boundary Layer of East China Sea. Journal of Geophysical Research: Atmospheres 2018, 123, (14), 76567669.

13. Biswas, A.; Blum, J. D.; Bergquist, B. A.; Keeler, G. J.; Xie, Z. Q., Natural Mercury 635 Isotope Variation in Coal Deposits and Organic Soils. Environ. Sci. Technol. 2008, 42, (22), 8303-8309.

14. Sun, R.; Sonke, J. E.; Heimburger, L. E.; Belkin, H. E.; Liu, G.; Shome, D.; Cukrowska,

15. Yin, R.; Feng, X.; Chen, J., Mercury Stable Isotopic Compositions in Coals from Major Coal Producing Fields in China and Their Geochemical and Environmental

16. Zheng, W.; Obrist, D.; Weis, D.; Bergquist, B. A., Mercury isotope compositions across North American forests. Global Biogeochem. Cycles 2016, 30, (10), 14751492.

17. Jiskra, M.; Wiederhold, J. G.; Skyllberg, U.; Kronberg, R. M.; Hajdas, I.; Kretzschmar, investigated with Hg isotope signatures. Environ Sci Technol 2015, 49, (12), 7188-96. 
651

652

653

654

655

656

657

658

659

660

661

662

663

664

665

666

667

668

669

670

671

672

673

674

675

676

677

678

679

680

681

682

18. Sherman, L. S.; Blum, J. D.; Johnson, K. P.; Keeler, G. J.; Barres, J. A.; Douglas, T. A., Mass-independent fractionation of mercury isotopes in Arctic snow driven by sunlight. Nat. Geosci. 2010, 3, (3), 173-177.

19. Fu, X.; Heimburger, L.-E.; Sonke, J. E., Collection of atmospheric gaseous mercury for stable isotope analysis using iodine- and chlorine-impregnated activated carbon traps. J. Anal. At. Spectrom. 2014, 29, (5), 841-852.

20. Fu, X.; Zhu, W.; Zhang, H.; Sommar, J.; Yu, B.; Yang, X.; Wang, X.; Lin, C. J.; Feng, X., Depletion of atmospheric gaseous elemental mercury by plant uptake at Mt. Changbai, Northeast China. Atmos. Chem. Phys. 2016, 16, (20), 12861-12873.

21. Sprovieri, F.; Pirrone, N.; Bencardino, M.; D'Amore, F.; Carbone, F.; Cinnirella, S.; Mannarino, V.; Landis, M.; Ebinghaus, R.; Weigelt, A.; Brunke, E. G.; Labuschagne, C.; Martin, L.; Munthe, J.; Wängberg, I.; Artaxo, P.; Morais, F.; Barbosa, H. D. M. J.; Brito, J.; Cairns, W.; Barbante, C.; Diéguez, M. D. C.; Garcia, P. E.; Dommergue, A.; Angot, H.; Magand, O.; Skov, H.; Horvat, M.; Kotnik, J.; Read, K. A.; Neves, L. M.; Gawlik, B. M.; Sena, F.; Mashyanov, N.; Obolkin, V.; Wip, D.; Feng, X. B.; Zhang, H.; Fu, X.; Ramachandran, R.; Cossa, D.; Knoery, J.; Marusczak, N.; Nerentorp, M.; Norstrom, C., Atmospheric mercury concentrations observed at ground-based monitoring sites globally distributed in the framework of the GMOS network. Atmos. Chem. Phys. 2016, 16, (18), 11915-11935.

22. McLagan, D. S.; Mitchell, C. P. J.; Huang, H.; Lei, Y. D.; Cole, A. S.; Steffen, A.; Hung, H.; Wania, F., A High-Precision Passive Air Sampler for Gaseous Mercury. Environmental Science \& Technology Letters 2016, 3, (1), 24-29.

23. McLagan, D. S.; Mitchell, C. P. J.; Steffen, A.; Hung, H.; Shin, C.; Stupple, G. W.; Olson, M. L.; Luke, W. T.; Kelley, P.; Howard, D.; Edwards, G. C.; Nelson, P. F.; Xiao, H.; Sheu, G. R.; Dreyer, A.; Huang, H.; Abdul Hussain, B.; Lei, Y. D.; Tavshunsky, I.; Wania, F., Global evaluation and calibration of a passive air sampler for gaseous mercury. Atmos. Chem. Phys. Discuss. 2018, 2018, 1-32.

24. Sun, R. Y.; Enrico, M.; Heimburger, L. E.; Scott, C.; Sonke, J. E., A double-stage tube furnace-acid-trapping protocol for the pre-concentration of mercury from solid samples for isotopic analysis. Anal. Bioanal. Chem. 2013, 405, (21), 6771-6781.

25. McLagan, D. S.; Huang, H.; Lei, Y. D.; Wania, F.; Mitchell, C. P. J., Application of sodium carbonate prevents sulphur poisoning of catalysts in automated total 
683

684

685

686

687

688

689

690

691

692

693

694

695

696

697

698

699

700

701

702

703

704

705

706

707

708

709

710

711

mercury analysis. Spectrochimica Acta Part B: Atomic Spectroscopy 2017, 133, 6062.

26. Method 1631, Revision E: Mercury in Water by Oxidation, Purge and Trap, and Cold Vapor Atomic Fluorescence Spectrometry; United States Environment Protection Agency: https://www.epa.gov/sites/production/files/201508/documents/method_1631e_2002.pdf , Washington, DC, 2002.

27. Smith, R. S.; Wiederhold, J. G.; Jew, A. D.; Brown, G. E.; Bourdon, B.; Kretzschmar, R., Stable Hg Isotope Signatures in Creek Sediments Impacted by a Former Hg Mine. Environmental Science \& Technology 2015, 49, (2), 767-776.

28. Stamenkovic, J.; Lyman, S.; Gustin, M. S., Seasonal and diel variation of atmospheric mercury concentrations in the Reno (Nevada, USA) airshed. Atmospheric Environment 2007, 41, (31), 6662-6672.

29. Lan, X.; Talbot, R.; Laine, P.; Lefer, B.; Flynn, J.; Torres, A., Seasonal and Diurnal Variations of Total Gaseous Mercury in Urban Houston, TX, USA. Atmosphere 2014, 5, (2), 399-419.

30. Carpi, A.; Chen, Y.-f., Gaseous Elemental Mercury as an Indoor Air Pollutant. Environmental Science \& Technology 2001, 35, (21), 4170-4173.

31. Horowitz, H. M.; Jacob, D. J.; Amos, H. M.; Streets, D. G.; Sunderland, E. M., Historical mercury releases from commercial products: global environmental implications. Environ. Sci. Technol. 2014, 48, (17), 10242-50.

32. Carpi, A.; Chen, Y.-f., Gaseous Elemental Mercury Fluxes in New York City. Water, Air, and Soil Pollution 2002, 140, (1), 371-379.

33. Xu, X. H.; Akhtar, U.; Clark, K.; Wang, X. B., Temporal Variability of Atmospheric Total Gaseous Mercury in Windsor, ON, Canada. Atmosphere 2014, 5, (3), 536556.

34. Cairns, E.; Tharumakulasingam, K.; Athar, M.; Yousaf, M.; Cheng, I.; Huang, Y.; Lu, J.; Yap, D., Source, concentration, and distribution of elemental mercury in the atmosphere in Toronto, Canada. Environ. Pollut. 2011, 159, (8), 2003-2008. 
712

713

714

715

716

717

718

719

720

721

722

723

724

725

726

727

728

729

730

731

732

733

734

735

736

737

738

35. Fu, X.; Feng, X.; Qiu, G.; Shang, L.; Zhang, H., Speciated atmospheric mercury and its potential source in Guiyang, China. Atmospheric Environment 2011, 45, (25), 4205-4212.

36. Chen, J.; Hintelmann, H.; Feng, X.; Dimock, B., Unusual fractionation of both odd and even mercury isotopes in precipitation from Peterborough, ON, Canada. Geochim. Cosmochim. Acta 2012, 90, (0), 33-46.

37. Sherman, L. S.; Blum, J. D.; Keeler, G. J.; Demers, J. D.; Dvonch, J. T., Investigation of local mercury deposition from a coal-fired power plant using mercury isotopes. Environ. Sci. Technol. 2012, 46, (1), 382-90.

38. Chesworth, W., Use of aluminum-amalgam in mineral synthesis at low temperatures and 1 atmosphere total pressure. Clays and Clay Minerals 1971, 19, (5), 337-339.

39. Estrade, N.; Carignan, J.; Sonke, J. E.; Donard, O. F. X., Mercury isotope fractionation during liquid-vapor evaporation experiments. Geochim. Cosmochim. Acta 2009, 73, (10), 2693-2711.

40. Ghosh, S.; Schauble, E. A.; Lacrampe Couloume, G.; Blum, J. D.; Bergquist, B. A., Estimation of nuclear volume dependent fractionation of mercury isotopes in equilibrium liquid-vapor evaporation experiments. Chem. Geol. 2013, 336, 5-12.

41. NADP NADP Site Selection and Installation Manual; http://nadp.isws.illinois.edu, $11.2014,2014$.

42. GMOS GMOS Standard Operational Procedure: Methods for the determination of TGM and GEM; http://www.gmos.eu/index.php/gmos-standard-operatingprocedures-sops, 7.4.2011, 2011. 